\title{
Thirteen-year growth response of ponderosa pine plantations to dominant shrubs (Arctostaphylos and Ceanothus)
}

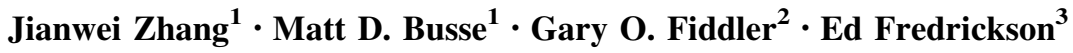

Received: 13 July 2018/ Accepted: 4 September 2018/Published online: 17 April 2019

(C) The Author(s) 2019

\begin{abstract}
Thirteen-year growth response of ponderosa pine to various manipulations of understory vegetation was studied to determine if a threshold of understory cover can be established for plantation productivity and whether nitrogen-fixing Ceanothus species benefit plantation growth compared to non N-fixing Arctostaphylos species, given their ability to improve site fertility. Results showed that completely controlling competing vegetation increased plantation growth, as was universally expected, but the effects of partial shrub control on plantation performance was inconsistent. We did not find a benefit of nitrogenfixing shrubs on tree growth, as young plantation growth was slightly better in the non $\mathrm{N}$-fixing plots compared to the $\mathrm{N}$-fixing plots due to differences in shrub cover. An understory cover threshold for tree growth was not observed. Due to the overriding effect of shrub competition, controlling herbaceous species had little effect on plantation growth even though it benefited tree seedling
\end{abstract}

Project funding: This work was supported by Forest Service Agenda 2020 Program and Sierra Cascade Intensive Forest Management Research Cooperative.

The online version is available at http://www.springerlink.com

Corresponding editor: Hu Yanbo.

Jianwei Zhang

jianweizhang@fs.fed.us

1 USDA Forest Service, Pacific Southwest Research Station, 3644 Avtech Parkway, Redding, CA 96002, USA

2 USDA Forest Service, Pacific Southwest Region, 3644 Avtech Parkway, Redding, CA 96002, USA

3 Thunder Road Resources, 21169 Falling Leaf Rd, Redding, CA 96003, USA survival. A long-term value of $\mathrm{N}$-fixing shrubs at these sites, if there is one, must be balanced by successful plantation establishment and rapid early growth.

Keywords Competing vegetation control · Manzanita . Nitrogen-fixing Ceanothus - Pinus ponderosa growth . Shrub cover

\section{Introduction}

Ponderosa pine (Pinus ponderosa Lawson \& C. Lawson) plantations represent one of the most frequently planted forests in the western United States. It is not only a very important timber species, but also a widely used species for post-fire forest regeneration. Early productivity of ponderosa pine plantations declines as understory competition increases (McDonald and Fiddler 2011; Zhang et al. 2013a, b). Growth is reduced as ground cover of woody shrubs approaches as little as 20\% (Shainsky and Radosevich 1986; White and Newton 1989), with the effect persisting well after trees have overtopped the brush. This relationship has been found at multiple sites (Oliver 1984) although the trends may change after overstory crown closure (Zhang et al. 2006, 2013a, b). Fiske (1982) concluded that pine plantations undergoing moderate competition from Arctostaphylos sp. ultimately would fail. Therefore, forest managers have tried to keep understory cover well-below the $20-30 \%$ threshold in young pine plantations.

Previous shrub control research conducted in California ponderosa pine plantations has yielded several site specific conclusions. By summarizing 32 studies established in northern and central California during 25 years, McDonald and Fiddler (2011) concluded that survival and growth of 
several species of conifers, including ponderosa pine, "were negatively correlated to the density, foliar cover, and height of various combinations of over 235 species of hardwoods, shrubs, forbs, and graminoids". They also found the effect of controlling competing vegetation on plantation growth varied considerably with site quality; competition would be too much when the foliar cover of undesirable plants exceeded $10-20 \%$ on poor sites and $20-30 \%$ on good sites. Reporting findings from a low productivity site in the Cascades, McDonald and Powers (2003) showed that trees growing with dense shrub cover produced less than $1 \%$ of the volume of trees growing free of shrub competition after 30 years. Oliver (1990) found that 20-year old stands with dense shrub cover achieved about half the volume of brush-free stands on a much more productive Sierra Nevada site. After crown closure, the effect of vegetation control on plantation growth dissipates, especially with the onset of self-thinning, although it takes many years for a stand to reach this stage on poor sites (Zhang et al. 2006, 2013a, b). Therefore, these long-term studies raise questions about the universality of shrub control prescriptions and how site quality influences longterm silvicultural response.

Plantation responses may also vary due to different understory communities (McDonald and Fiddler 2011). Previous reviews suggest that nitrogen fixed by Ceanothus could be important to conifer site productivity (Johnson 1995). For example, annual rates of $\mathrm{N}$ fixation by full stocking of $C$. velutinus could be as high as $100 \mathrm{~kg} \mathrm{~N} \mathrm{ha}^{-1} \mathrm{a}^{-1}$ on the western slope of the Cascades (Binkley et al. 1982; McNabb and Cromack 1983; Youngberg and Wollum 1976). The long-term presence of $\mathrm{N}$-fixing shrubs has been shown to improve several measures of soil quality, i.e., higher soil nitrogen and carbon and nitrogen ratio, with no evidence of improved ponderosa pine growth (Busse et al. 1996).

In this study, we analyzed data collected from plantations established at two sites in 2005 to determine (1) the effect of varying degrees of shrub competition on plantation performance and (2) whether nitrogen-fixing shrubs (Ceanothus) benefit plantation growth compared to non $\mathrm{N}$-fixing shrubs (Arctostaphylos).

\section{Materials and methods}

The study was established at two sites in northern California, Dana (Lat. 41.1416, long. 121.6385, Elev. $1259 \mathrm{~m}$ ) a low to moderately productive site, and Flatwoods (Lat. 40.9665, Long. 121.9495, Elev. $889 \mathrm{~m}$ ) a highly productive site. Although the two sites are only $30 \mathrm{~km}$ apart, it is cooler and much drier at Dana than Flatwoods, with mean annual temperature $11.2{ }^{\circ} \mathrm{C}$ and $14.6{ }^{\circ} \mathrm{C}$ and annual precipitation $775 \mathrm{~mm}$ and $1880 \mathrm{~mm}$, respectively from 2004 to 2016. The soil is the Jimmerson loam-Jimmerson stony sandy loam complex at Dana and a Cohasset-Aiken stony loams at Flatwoods, with similar soil depths of about $200 \mathrm{~cm}$. Eleven treatments and control (12 experimental units) were randomly replicated four times at each site. These included the following vegetation targets at year 5 after tree planting:

(1) No vegetation control (NVC)

(2) Full vegetation control (FVC)

(3) Arctostaphylos cover: 5, 15, 30, or $50 \%$

(4) Ceanothus cover: $5,15,30$, or $50 \%$

(5) Herbaceous vegetation present with full shrub control (Herb 0)

(6) Herbaceous vegetation controlled after one growing season (full shrub control) (Herb 1)

Each plot $(0.25 \mathrm{ac})$ was split, and one half of the plot was planted with ponderosa pine seedlings and the other half was planted with Douglas-fir seedlings in spring of 2005. Spacing for both species was 2.5 by $2.5 \mathrm{~m}$. The four Arctostaphylos treatments were accomplished by naturally growing and a transplanting of shrubs from the adjacent forests. Ceanothus cover developed from native seed caches and sprouting of live shrubs; $C$. cordulatus and $C$. prostratus were at Flatwoods and $C$. integerimus and $C$. prostratus at Dana. All Douglas-fir split plots showed very low survival and were eliminated from the study. Treatment activities included: (1) field sites were harvested and prepared for planting in 2004 and 2005. (2) 96 plots were installed and Douglas-fir and ponderosa pine seedlings were planted in 2005. (3) Herbicide treatments of $5 \%$ Accord XRT II plus 5\% MSO (methylated seed oil) were applied to all vegetation in the FVC plots, all vegetation excluding Arctostaphylos and Ceanothus in the targeted brush cover plots and to the woody brush in Herb 0 and Herb 1 treatments in 2005. The treatments were repeated in 2006 with the exception of the Herb 1 treatment where the herbaceous vegetation was also controlled. (4) Arctostaphylos seedlings were transplanted in 2006 and 2007. (5) Shrub cover was measured in 2008. (6) Shrub cover was adjusted by both manual grubbing and full strength Garlon 3A application to meet original cover percentage targets for Arctostaphylos and Ceanothus treatments at Flatwoods in 2009. (7) Shrub cover was re-measured in 2014. (8) Ponderosa pine was measured in 2017.

We measured diameter at $1.37 \mathrm{~m}(\mathrm{DBH})$ for the inner 20 ponderosa pine trees in all plots after the 2017 growing season. Tree height and height to live crown were measured on every other tree within each measurement plot. Shrub cover was sampled using a line-intercept method on four parallel $10 \mathrm{~m}$ transects. Species were identified and grouped as Arctostaphylos sp., Ceanothus sp., other shrubs, 
and naturally regenerated hardwoods and conifers; all were regarded as woody species. C. prostratus was separately recorded and analyzed from other Ceanothus sp. due to its growth habit as a ground covering carpet.

\section{Data analyses}

We analyzed tree $\mathrm{DBH}$, height, basal area (BA), tree survival rate, and all understory vegetation covers using analysis of variance in SAS PROC MIXED with plot as random effects and treatment and site with fixed effect. A general model was:

$y_{i j k}=\mu+\alpha_{i}+\gamma_{j}+\alpha \gamma_{i j}+\varepsilon_{i j k}$

where $y_{i j k}$ is the dependent variable measured for the $i$ th treatment, the $j$ th site, and $k$ th replication, $\mu$ is the overall mean, $\alpha_{i}$ is the fixed effect of the $i$ th treatment $(\mathrm{i}=1,2$, $\ldots), \gamma_{j}$ is the fixed effect of the $j$ th site $(\mathrm{j}=1$ and 2$)$, which was treated as fixed because we want to estimate the site by treatment interactions, $\alpha \gamma_{i j}$ and $\varepsilon_{i j k}$ is an experimental error, $\varepsilon_{i j k} \sim \operatorname{iidN}\left(0, \sigma_{e}^{2}\right)$.

For each variable analysis, residuals were examined to ensure that statistical assumptions of normality and homoscedasticity were met. If not, a natural $\log$ or squareroot transformation was applied. During the model selection process, we selected the model with the minimum Akaike information criterion (AIC). Multiple comparisons among treatments were conducted for least squares means by the Tukey-Kramer test by controlling for the overall $\alpha=0.1$.

\section{Results and discussion}

Treatment effect was significant for all variables $(p<0.001)$. For trees, the differences were mainly caused by NVC and FVC, the two extreme treatments (Table 1). $\mathrm{DBH}$, height, and BA were significantly higher in FVC than in NVC treatments. There were some exceptions from these trends. For example, controlling shrubs but not herbaceous species (Herb 0) resulted in smaller DBH and HT, and lower BA than FVC, Herb 1, and some manipulated shrub cover treatments. The NVC plots and no herbaceous control plots showed a lower survival rate than other treatments at both sites. However, fewer trees on the plots did not yield larger trees in these treatments as we expected, although they carry less basal area. The two sites differed significantly in height, BA, and survival $(p<0.043)$, with average height $4.6 \mathrm{~m}$ and $5.3 \mathrm{~m}$, BA $13.8 \mathrm{~m}^{2} \mathrm{ha}^{-1}$ and $16.2 \mathrm{~m}^{2} \mathrm{ha}^{-1}$, and survival rate 0.64 and 0.79 at Dana and Flatwoods, respectively. Tree DBH was greater at Dana than Flatwoods $(12.1$ and $11.5 \mathrm{~cm}$, respectively) due to lower survival at Dana.

Trees grew better on Arctostaphylos plots than on Ceanothus plots, especially at Flatwoods, which might be due to a greater cover of Ceanothus than Arctostaphylos. For understory shrubs (Fig. 1), Arctostaphylos grew better, but non-significantly, at Dana than Flatwoods through 2014 (Table 2). But, the trends were reversed with $p<0.001$ for Ceanothus species in both 2008 and 2014. From the 2008 data, we can tell that shrubs, mainly $C$. cordulatus, invaded much faster and more aggressively at Flatwoods. Significant treatment effect on shrub cover was obvious by completely eliminating shrubs or letting them develop naturally, with manipulation for both Arctostaphylos and Ceanothus crown covers (Fig. 1). Even so from the beginning and continuing in 2009, the targeted cover percentages were not achieved; for example, the 15\% Arctostaphylos cover was the highest cover percentage at Dana in 2014. Due to plot variation, site effect and site by treatment interaction were not significant for total woody species cover in 2014 (Table 2). But, treatment effect was significant with FVC, Herb 0, and Herb 1 showing less cover because understory woody species were controlled in the early years.

The threshold of shrub density for both Arctostaphylos and Ceanothus could not be found from our manipulated percentage. However, we found weak and non-significant negative relationships between growth variables (height and BA) and shrub cover (Fig. 2). The results were not expected because previous studies always found strong negative relationships between shrub cover and tree growth. We offer several possible explanations. One possibility might be a lack of complete establishment of Arctostaphylos cover regimes. But, relationships were not tighter by eliminating these plots. Second was low tree survival rate on some plots, mainly on no-vegetation control and without herbaceous release. After we eliminated the plots with survival rate $\leq 0.5$, the relationship significantly improved due to a strong positive relationship between tree density and BA (Fig. 3). Finally, the inconsistent shrub development prior to 2009 and shrub cover manipulation in 2009 might have interrupted stand development. For example, when a higher shrub cover was artificially reduced to a lower cover, tree growth that was reduced by competing shrubs could not be added in 2009 . Thus, the relationship between plantation growth and understory cover percentage might have been changed and affected. In addition, Zhang et al. (2006) failed to find differences in ponderosa pine plantations grown with full shrub cover from those grown with $50 \%$ shrub cover. Our studies reflect the difficulty in controlling understory cover to a targeted percentage year after year as the shrubs rapidly occupied these sites. However, plantation growth 
Table 1 Means, standard errors, and $p$ values for testing fixed effect terms for $\mathrm{DBH}$, height (HT), basal area (BA), and survival rate for ponderosa pine grown at Dana and Flatwoods in northern California

\begin{tabular}{lllll}
\hline Tree measurement & DBH $(\mathrm{cm})$ & $\mathrm{HT}(\mathrm{m})$ & $\mathrm{BA}\left(\mathrm{m}^{2} \mathrm{ha}^{-1}\right)$ & Survival rate \\
\hline Site effect & & & & \\
$\quad$ Dana & $12.1(0.30) \mathrm{a}$ & $4.6(0.12) \mathrm{a}$ & $13.8(0.93) \mathrm{a}$ & $0.65(0.04) \mathrm{a}$ \\
Flatwoods & $11.5(0.39) \mathrm{b}$ & $5.3(0.19) \mathrm{b}$ & $16.3(1.18) \mathrm{b}$ & $0.79(0.04) \mathrm{b}$ \\
Treatment effect & & & \\
NVC & $8.0(0.93) \mathrm{a}$ & $3.1(0.32) \mathrm{a}$ & $3.4(1.24) \mathrm{a}$ & $0.34(0.09) \mathrm{a}$ \\
FVC & $14.4(0.55) \mathrm{b}$ & $6.1(0.35) \mathrm{b}$ & $23.2(2.60) \mathrm{b}$ & $0.79(0.05) \mathrm{b}$ \\
Arctostaphylos 5\% & $12.4(0.61) \mathrm{bc}$ & $5.4(0.27) \mathrm{bc}$ & $19.5(1.62) \mathrm{b}$ & $0.89(0.03) \mathrm{b}$ \\
Arctostaphylos 15\% & $12.3(0.60) \mathrm{bc}$ & $5.1(0.32) \mathrm{bcd}$ & $16.9(1.81) \mathrm{bc}$ & $0.79(0.04) \mathrm{b}$ \\
Arctostaphylos 30\% & $12.3(0.85) \mathrm{bc}$ & $5.4(0.32) \mathrm{bc}$ & $17.3(2.08) \mathrm{bc}$ & $0.80(0.06) \mathrm{b}$ \\
Arctostaphylos 50\% & $13.0(0.69) \mathrm{bc}$ & $5.6(0.45) \mathrm{bc}$ & $17.4(1.71) \mathrm{bc}$ & $0.74(0.06) \mathrm{bc}$ \\
Ceanothus 5\% & $12.1(0.71) \mathrm{bc}$ & $5.1(0.19) \mathrm{bcd}$ & $13.9(1.42) \mathrm{cd}$ & $0.73(0.09) \mathrm{bc}$ \\
Ceanothus 15\% & $11.2(0.60) \mathrm{c}$ & $4.8(0.27) \mathrm{cd}$ & $14.4(2.56) \mathrm{cd}$ & $0.73(0.10) \mathrm{bc}$ \\
Ceanothus 30\% & $10.7(0.87) \mathrm{c}$ & $4.7(0.44) \mathrm{cd}$ & $14.0(2.44) \mathrm{cd}$ & $0.79(0.06) \mathrm{b}$ \\
Ceanothus 50\% & $10.8(0.81) \mathrm{c}$ & $4.7(0.20) \mathrm{cd}$ & $13.3(2.17) \mathrm{cd}$ & $0.78(0.08) \mathrm{b}$ \\
Herb 0 & $11.1(0.70) \mathrm{c}$ & $4.0(0.39) \mathrm{d}$ & $8.8(2.62) \mathrm{d}$ & $0.44(0.11) \mathrm{c}$ \\
Herb 1 & $13.1(0.57) \mathrm{bc}$ & $5.3(0.22) \mathrm{bc}$ & $18.2(2.09) \mathrm{b}$ & $0.76(0.08) \mathrm{b}$ \\
p values & & & & 0.006 \\
Site (1, 70)* & 0.098 & $<0.001$ & $<0.001$ & $<0.001$ \\
Treatment (11, 70) & $<0.001$ & $<0.001$ & 0.189 & 0.851 \\
Site*Trtmt (11, 70) & 0.172 & 0.161 &
\end{tabular}

The different letters within either the site effect or treatment effect indicate $p<0.10$

*Numbers in the parentheses are the degrees of freedom will significantly increase when competing vegetation is completely controlled.

In these young ponderosa pine plantations, nitrogenfixing shrubs (Ceanothus) did not show benefits to plantation growth compared to non N-fixing shrubs (Arctostaphylos). Trees were considerably smaller on the Ceanothus plots than on the Arctostaphylos plots (Table 1). As we suggested earlier, shrub cover was much higher on Ceanothus plots than on Arctostaphylos plots at both sites, which may explain the results. Based on 6-year results from a young ponderosa pine study, Powers and Ferrell (1996) concluded that shrub control was essential for satisfactory plantation performance on poor, droughty sites. Moisture availability is the most common factor limiting plant growth in temperate regions of Mediterranean climate. Consequently, competition for soil moisture is considered the main mechanism of interaction between ponderosa pine and other vegetation. McDonald and Fiddler (1990) reported predawn plant water potential was 0.7 MPa higher in pine plots kept shrub-free with herbicides than the shrub intact plots. Because soil moisture was such an overriding factor, fertilizer application after shrub control offered no further advantage beyond shrub control alone at a low quality site (Powers and Ferrell 1996; Powers and Reynolds 1999). They hypothesized that shrubs block uptake of fertilizer nutrients by pine. If this is true, it may help explain a lack of tree growth enhancement by nitrogen-fixing shrubs in this study.

An effect of controlling herbaceous species was nonsignificant except for survival at Flatwoods (Table 1). Yet, tree growth responded to the treatment positively, especially at Dana. Although not significant, DBH, height, basal area and survival increased with herbaceous vegetation control in the second year with the Herb 1 treatment compared to Herb 0 where herbaceous plants were not controlled at all. This also may show that herbaceous vegetation can affect growth and survival past the first growing season. The trend was less apparent in the Flatwoods with the exception of survival but this may be due to the better site quality at Flatwoods. This suggests that at a xeric site, any increase in soil water availability will help tree performance. White and Newton (1989) have shown the importance of herbaceous weed control on survival and growth and that herbs can extract moisture as deeply as $0.9 \mathrm{~m}$.

In summary, our results showed that completely controlling competing vegetation increased plantation growth. However, relationships between partial control and the performance of trees were more complicated. We did not find that nitrogen-fixing shrubs provided benefits to plantation growth. On the contrary, young plantation growth on non $\mathrm{N}$-fixing species plots was slightly better than on 

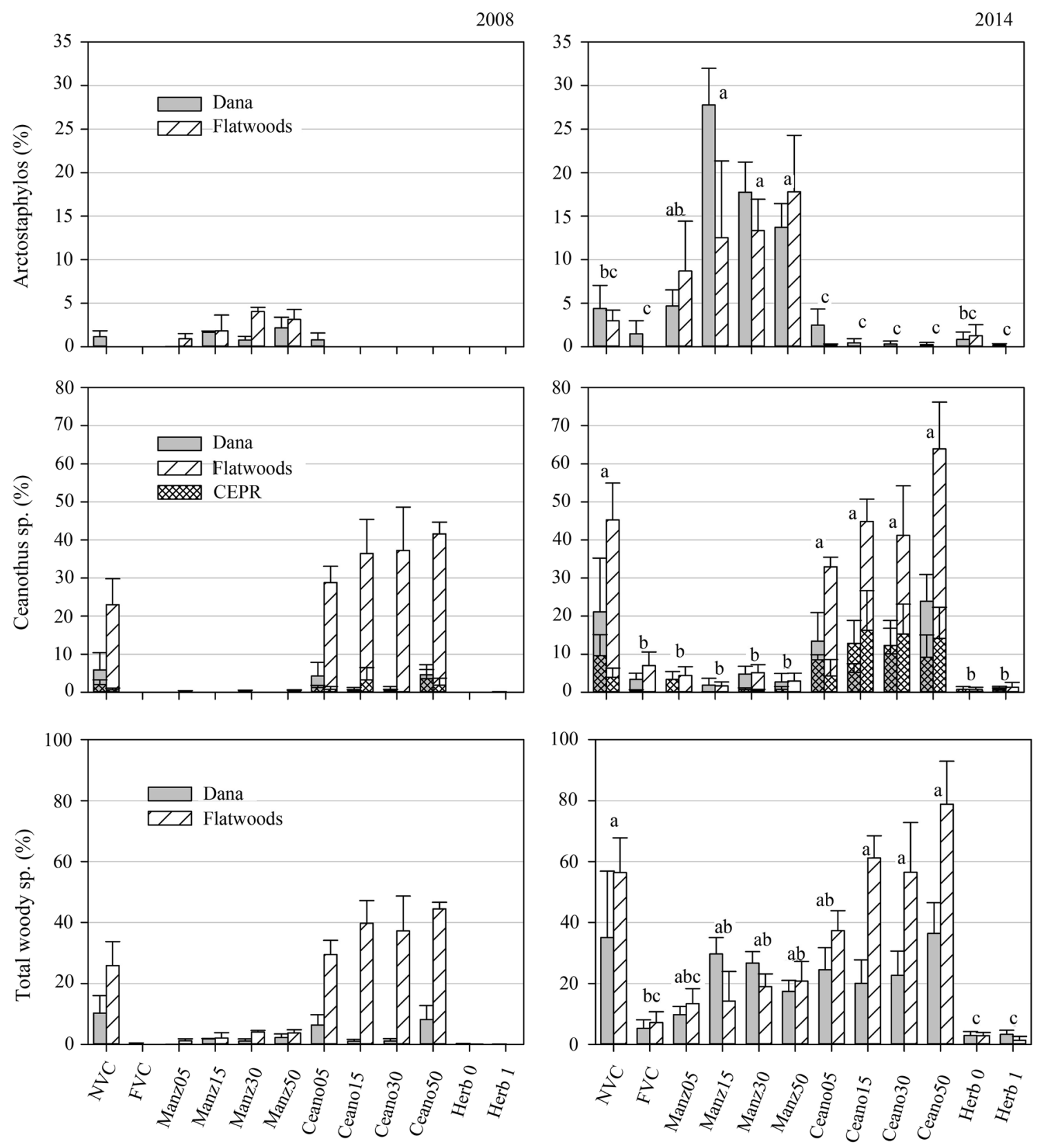

Treatment

Fig. 1 Means and standard errors of Arctostaphylos sp., Ceanothus sp., and total woody species cover across various treatments at both Dana and Flatwoods measured in 2008 and 2014. Due to the significant site by treatment interactions caused by many zero crown cover in 2008, multiple comparisons were not presented here.

$\mathrm{N}$-fixing species plots due to differences in shrub cover. Neither did we find an understory density threshold for tree growth. Due to the overriding effect of shrub competition, controlling herbaceous species increased tree survival but
Whereas in 2014, no interactions are found for any variables, the treatment differences are indicated by different letters $(p<0.10)$. Ceanothus prostrates (CEPR) had the same trends as other Ceanothus species in the multiple comparisons

did not significantly affect plantation growth. A long-term value of $\mathrm{N}$-fixing shrubs must be balanced by successful plantation establishment and rapid early growth. 
Table 2 Source of variation, numerator and denominator degree of freedom, and probability $(\operatorname{Pr}>F)$ for testing fixed effects for the covers of total understory woody species, Arctostaphylos sp., and
Ceanothus sp. excluding C. prostrates which is separately analyzed due to its small stature as a ground covering carpet at Dana and Flatwoods in northern California

\begin{tabular}{llcccccc}
\hline Year & Source of variation & Num df & Den df & Woody species & Arctostaphylos species & Ceanothus species & C. prostratus \\
\hline 2008 & Site & 1 & 70 & $<0.001$ & 0.466 & $<0.001$ & $<0.001$ \\
& Treatment & 11 & 70 & $<0.001$ & $<0.001$ & $<0.001$ & 0.022 \\
& Site * Treatment & 11 & 70 & $<0.001$ & 0.037 & 0.001 & 0.902 \\
2017 & 1 & 70 & 0.515 & 0.122 & $<0.001$ & 0.119 \\
& Site & 11 & 70 & $<0.001$ & $<0.001$ & 0.001 \\
& Treatment & 11 & 70 & 0.734 & 0.631 & 0.98 \\
\hline
\end{tabular}

8
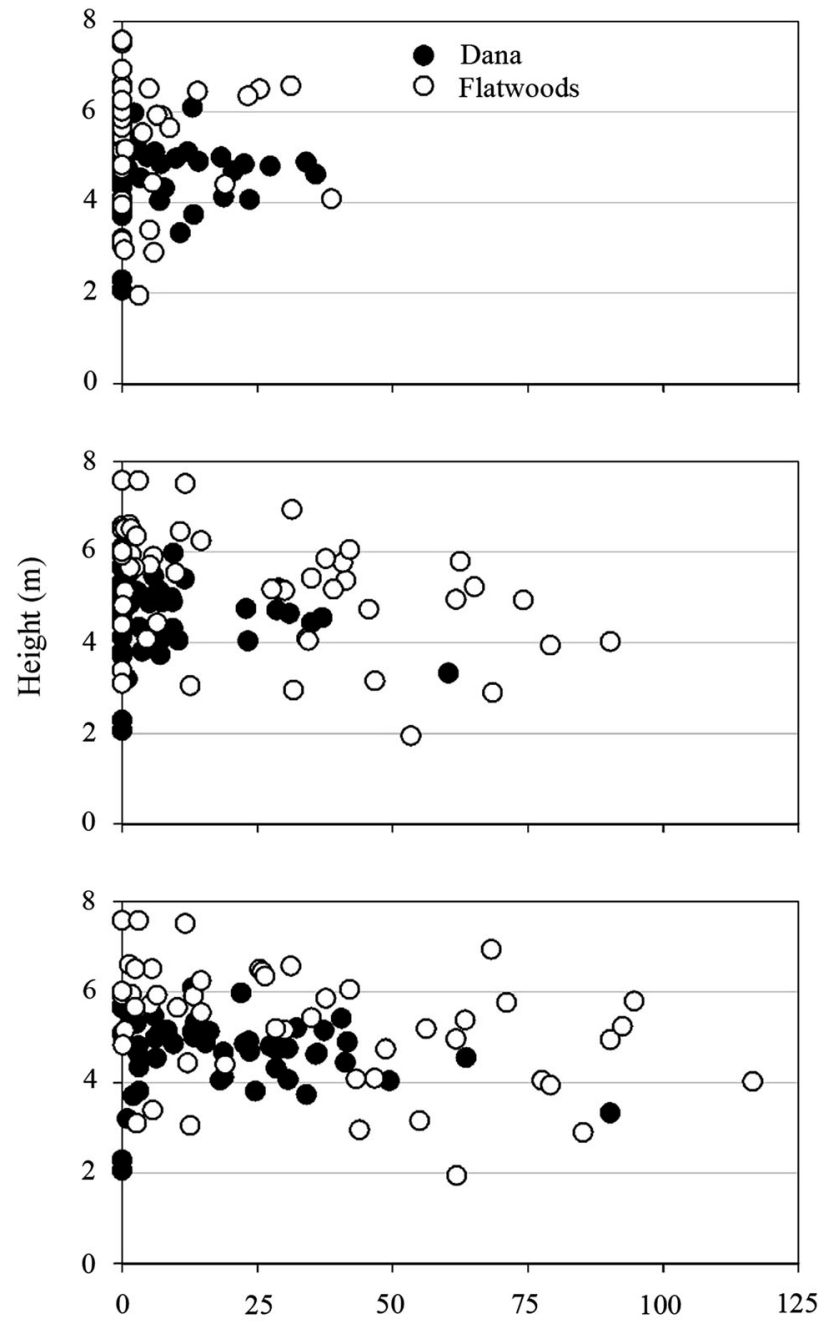
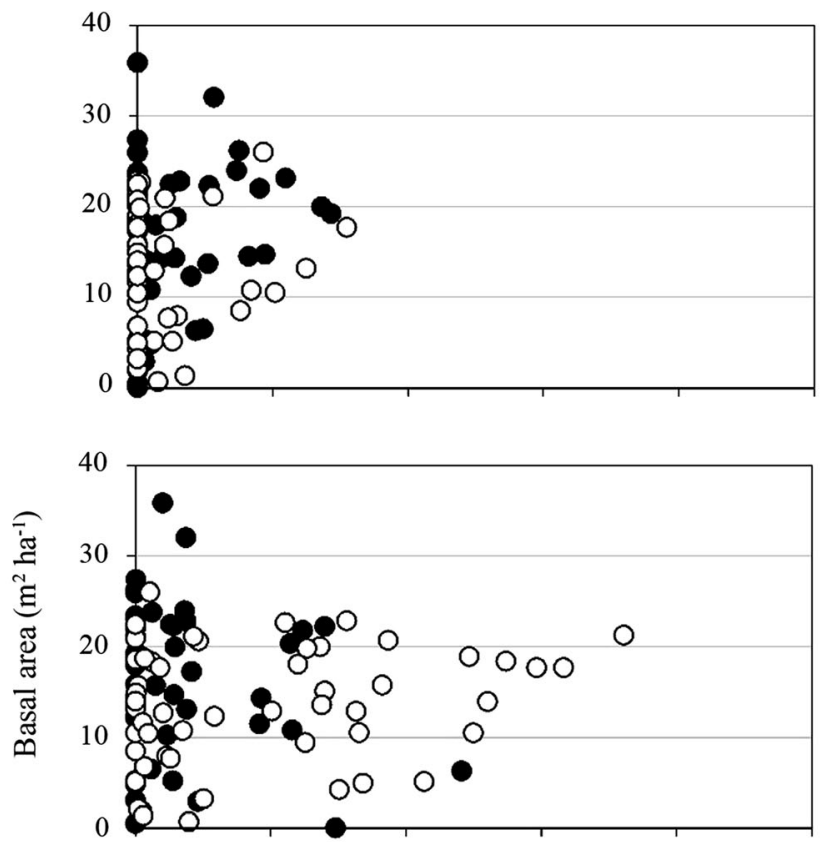



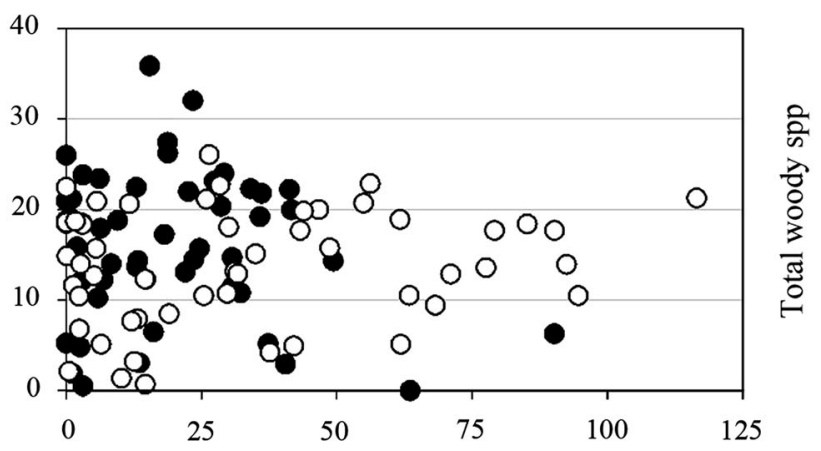

Woody understory cover (\%)

Fig. 2 Relationships between woody understory cover (\%) and 13th-year height and total basal area for ponderosa pine grown on various understory manipulation treatments and control on the Agenda 2020 sites at Dana and Flatwoods in northern California 


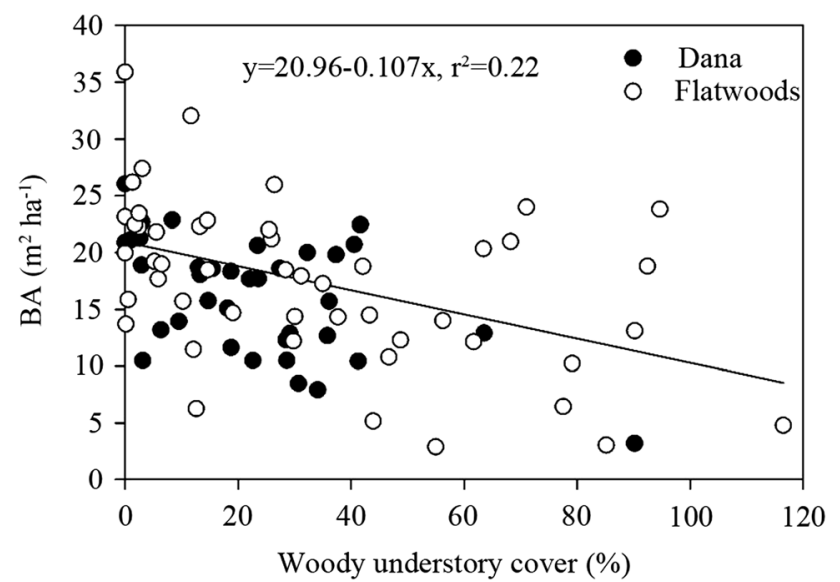

Fig. 3 Relationship between woody understory cover (\%) and 13thyear total basal area with tree survival rate greater than and equal to $50 \%$ for ponderosa pine grown on various understory manipulation treatments and control on the Agenda 2020 sites at Dana and Flatwoods in northern California

Acknowledgements Our late colleague Dr. Robert F. Powers designed the study and oversaw the installation and earlier data collection. Thanks to Roseburg Forest Resources, W.M. Beaty \& Associates, Inc., and Sierra Pacific Industries for installing the study at their site; David Young for marking shrubs, Alice Ratcliff and Carol Shestak for measuring shrub cover; and Kaelyn Finley for organizing the data. Comments from Kaelyn Finley and Dr. Chrissy Howell for improving the manuscript were greatly appreciated. Use of trade names in this paper does not constitute endorsement by the United States Forest Service.

Open Access This article is distributed under the terms of the Creative Commons Attribution 4.0 International License (http://crea tivecommons.org/licenses/by/4.0/), which permits unrestricted use, distribution, and reproduction in any medium, provided you give appropriate credit to the original author(s) and the source, provide a link to the Creative Commons license, and indicate if changes were made.

\section{References}

Binkley D, Cromack K Jr, Fredriksen RL (1982) Nitrogen accretion and availability in some snowbrush ecosystems. For Sci 28:720-724

Busse MD, Cochran PH, Barrett JW (1996) Changes in ponderosa pine site productivity following removal of understory vegetation. Soil Sci Soc Am J 60:1614-1621

Fiske JN (1982) Evaluating the need for release from competition from woody plants to improve conifer growth rates. In:
Proceedings, third annual forest vegetation management conference, 4-5 November 1981, Redding, CA, pp 25-44

Johnson DW (1995) Soil properties beneath Ceanothus and pine stand in the eastern Sierra Nevada. Soil Sci Soc Am J 59:918-924

McDonald PM, Fiddler GO (1990) Ponderosa pine seedlings and competing vegetation: ecology, growth, and cost. USDA Forest Service, Berkeley, CA, Pacific Southwest Research Station, Research Paper PSW-199

McDonald PM, Fiddler GO (2011) Twenty-five years of managing vegetation in conifer plantations in northern and central California: results, application, principles, and challenges. Gen. Tech. Rep. PSW-GTR-231. USDA Forest Service, Pacific Southwest Research Station, Albany, CA

McDonald PM, Powers RF (2003) Vegetation trends and carbon balance in a ponderosa pine plantation: long-term effects of different shrub densities. In: Proceedings, 24th annual forest vegetation management conference, 14-16 January 2003. Redding, CA, pp 25-43

McNabb DH, Cromack K Jr (1983) Dinitrogen fixation by a mature Ceanothus velutinus (Dougl.) stand in the western Oregon Cascades. Can J Microbiol 29:1014-1021

Oliver WW (1984) Brush reduces growth of thinned ponderosa pine in northern California. USDA Forest Service, Berkeley, CA, Pacific Southwest Research Station, Research Paper PSW-172

Oliver WW (1990) Spacing and shrub competition influence 20-year development of planted ponderosa pine. West J Appl For 5:79-82

Powers RF, Ferrell GT (1996) Moisture, nutrient, and insect constraints on plantation growth: the "Garden of Eden" study. NZ J For Sci 26:126-144

Powers RF, Reynolds PE (1999) Ten-year responses of ponderosa pine plantations to repeated vegetation and nutrient control along an environmental gradient. Can J For Res 29:1027-1038

Shainsky LJ, Radosevich SR (1986) Growth and water relations of Pinus ponderosa seedlings in competitive regimes with Arctostaphylos patula seedlings. J Appl Ecol 23:957-966

White DE, Newton M (1989) Competitive interactions of whiteleaf manzanita, herbs, Douglas-fir, and ponderosa pine in southwest Oregon. Can J For Res 19:232-238

Youngberg CT, Wollum AG (1976) Nitrogen accretion in developing Ceanothus velutinus stands. Soil Sci Soc Am J 40:109-112

Zhang JW, Oliver WW, Busse MD (2006) Growth and development of ponderosa pine on sites of contrasting productivities: relative importance of stand density and shrub competition effects. Can J For Res 36:2426-2438

Zhang JW, Oliver WW, Ritchie MW, Neal DL (2013a) Overstory and understory dynamics in a ponderosa pine plantation varying with stand density in the Sierra Nevada: 40-year results. For Sci 59(6):670-680

Zhang JW, Powers RF, Oliver WW, Young DH (2013b) Response of ponderosa pine plantations to competing vegetation control in Northern California, USA: a meta-analysis. Forestry 86:3-11

Publisher's Note Springer Nature remains neutral with regard to jurisdictional claims in published maps and institutional affiliations. 